
Not for reproduction, distribution or commercial use.

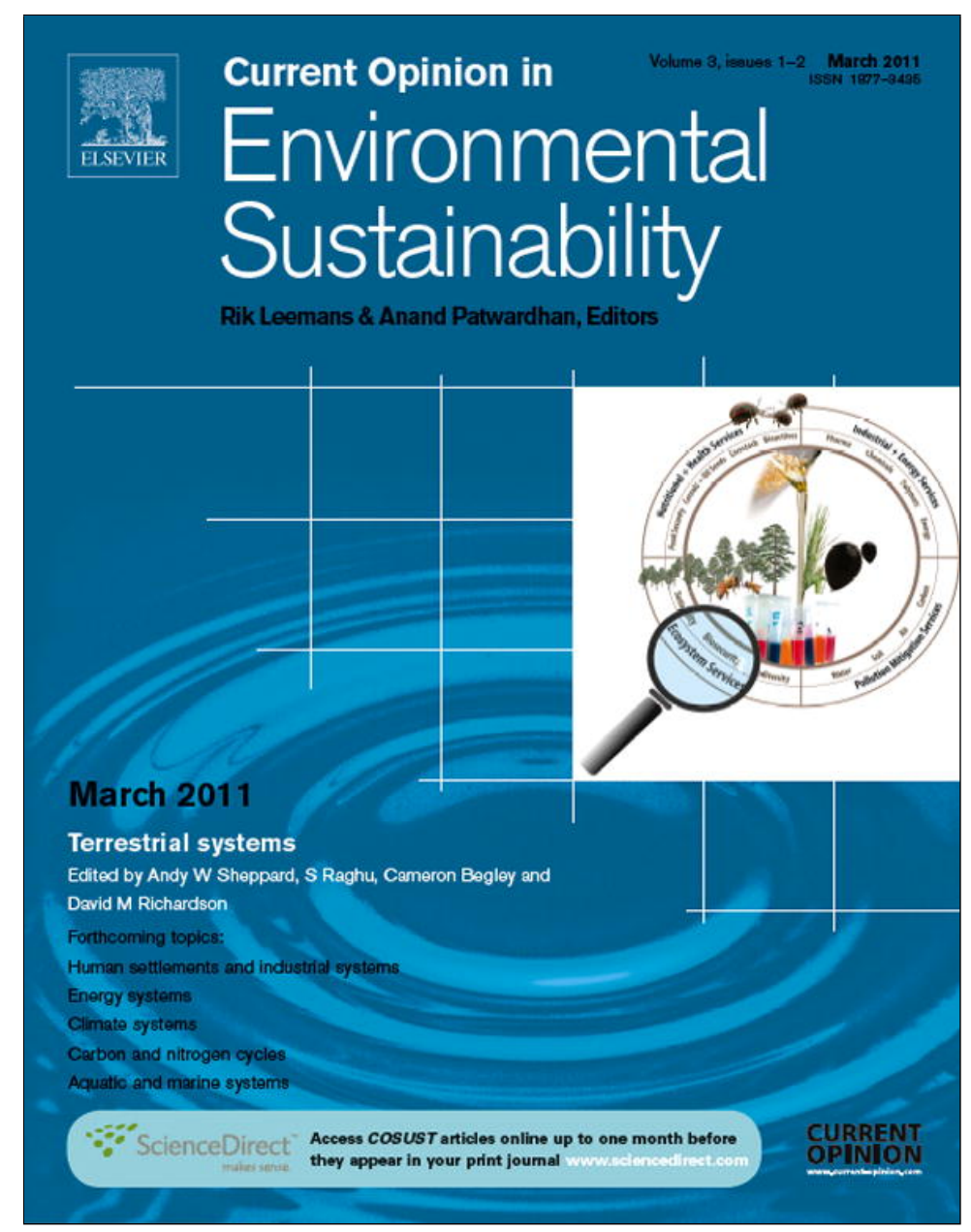

This article appeared in a journal published by Elsevier. The attached copy is furnished to the author for internal non-commercial research and education use, including for instruction at the authors institution and sharing with colleagues.

Other uses, including reproduction and distribution, or selling or licensing copies, or posting to personal, institutional or third party websites are prohibited.

In most cases authors are permitted to post their version of the article (e.g. in Word or Tex form) to their personal website or institutional repository. Authors requiring further information regarding Elsevier's archiving and manuscript policies are encouraged to visit:

http://www.elsevier.com/copyright 


\section{Learning from our mistakes: minimizing problems with invasive biofuel plants} David M Richardson ${ }^{1}$ and Ryan Blanchard ${ }^{1,2}$

One of the environmental concerns associated with producing biofuels from alien plants is the risk of these species becoming invasive. We explored whether insights from commercial forestry and agroforestry could inform strategies to reduce future problems with invasive biofuel plants. The dynamics, dimensions, and extent of invasions of forestry species can be explained using models incorporating species traits, environmental features, stochastic factors associated with plantings, and residence time. Economic driving forces are crucial.Important lessons to be learnt from forestry for reducing problems with invasiveness of alien species for biofuel production include: the use of global databases and screening tools for identifying high-risk species; the design and configuration of plantations to minimize spread risk; and the use of biological control to reduce invasiveness.

\section{Addresses}

${ }^{1}$ Centre for Invasion Biology, Department of Botany \& Zoology, Stellenbosch University, Matieland 7602, South Africa

${ }^{2}$ Centre for Invasion Biology, CSIR Natural Resources and the Environment, P.O. Box 320, Stellenbosch 7599, South Africa

Corresponding author: Richardson, David M (rich@sun.ac.za)

Current Opinion in Environmental Sustainability 2011, 3:36-42

This review comes from a themed issue on Terrestrial systems Edited by Andy W Sheppard, S Raghu, Cameron Begley and David M Richardson

Received 17 August 2010; Accepted 15 November 2010 Available online 16th December 2010

$1877-3435 / \$$ - see front matter

(C) 2010 Elsevier B.V. All rights reserved.

DOI 10.1016/j.cosust.2010.11.006

\section{Introduction}

The current energy crisis, the need to reduce $\mathrm{CO}_{2}$ emissions, and a range of geopolitical issues leading to many nations needing to reduce their dependence on fossil fuels have raised interest in the use of biofuels [1]. This new bioeconomy is responsible for strong economic incentives to use plants, including transgenic cultivars, non-native species, and taxa formerly confined to small geographical areas, as biofuel feedstock across large areas [2]. Biofuel production is controversial because although it promises numerous benefits, it holds considerable economic, social, and environmental risks [2-4].

Biofuel production is not new, but meeting the growing need for environmentally friendly fuels is driving a shift from current biofuel feedstocks to a new suite of species. Most biofuel is currently produced from food plant species (e.g., maize and sugarcane) which are well known, have been domesticated for centuries, and occupy large areas of arable land [5]. Many of the alternative non-food plant species currently being developed or under consideration for biofuels are known to be invasive (i.e. they spread from sites where they are cultivated, often resulting in undesirable impacts) somewhere in the world, or are very likely to be invasive if introduced to new regions and cultivated in large numbers $\left[6,7^{\bullet \bullet}\right]$. Characteristics that make them attractive as biofuel feedstocks (wide environmental tolerance, rapid growth, ease of establishment, low water demand, ability to resprout when harvested, prolific seed production, etc.) are precisely those traits which predispose plant species to become invasive [8].

Potential problems with invasive biofuel plants have been addressed in many publications in the peer-reviewed and grey literature recently. Among the topics that have received attention are:

- General discussions about how biofuel production could exacerbate problems with invasions $[9,10]$.

- The development of guidelines to prevent invasive species from invading areas outside sites set aside for biofuel production, for example [11-13].

- The formulation of guidelines for integrating concerns about the invasiveness of biofuel species into national environmental policies [14].

- The application of weed risk-assessment systems for screening potential biofuel species for invasive potential in different regions $\left[7^{\bullet \bullet}, 15\right]$.

- Elaboration of the dimensions of conflicts of interest between national authorities responsible for fuel provision and environmental agencies [2];

- Discussion of various technologies to produce 2nd generation fuels and the implication for new plant feedstocks [16].

We review problems with plant invasions associated with the cultivation of alien plants for two purposes with a much longer history than biofuel production - commercial forestry and agroforestry - and the evolution of approaches to manage these problems. We extract key lessons and principles from the experience in these endeavours that could be applied to reduce problems should alien plants be widely disseminated and cultivated for biofuel production. Special attention is given to the situation in the Southern Hemisphere. 


\section{Commercial forestry}

Despite its long history, sustained, large-scale forestry was limited until the late 19th century in Europe, and only expanded to other parts of the world in the 20th century $[17,18]$. The rapid growth of the forestry industry can be linked to the growing demands of human populations and evolving technology creating a close link between the forestry, timber, pulp and paper (FTPP) industries of the world. These industries are closely linked with consumer products traded on international markets, and thus are increasingly subject to codes of conduct relating to sustainability. It is only recently that environmental issues, including invasiveness, have emerged as important considerations in the industry [19].

In the Southern Hemisphere, afforestation with alien trees increased dramatically in the second half of the 20th century, and plantations of trees, mainly pines and eucalypts, are now a dominant feature of landscapes in many countries. For pines, the expansion of plantations in Chile (early 1970s) Australia (early 1960s) and New Zealand (late 1960s) has been phenomenal: by 1996 roughly 4 million ha had been planted to Pinus radiata alone.

The invasive spread of pines from planting sites in the Southern Hemisphere was first noted in the mid-1800s in South Africa, and widespread invasions were reported by the 1920s. Widespread invasions were noted somewhat later in Australia and New Zealand [20]. Large-scale plantings took place much later in South America than in the aforementioned regions, and widespread invasions there are consequently more recent [21]. At least 17 Pinus species, out of the $>100$ species in the genus (most of which have been planted to some extent) are now well established as invaders of natural ecosystems in the southern hemisphere, and eight species are major environmental weeds.

Pine invasions in the Southern Hemisphere can be explained by a model incorporating information on species attributes, residence time, the extent of planting, ground-cover characteristics, locality (latitude), disturbance regime, and the resident biota in the receiving environment [22]. The syndrome of traits that separate invasive from non-invasive pine species [23] has been shown to be useful for separating invasive from non-invasive taxa in other conifers [24] and indeed in woody plants in general [25], underscoring the value of the natural experiment of pine afforestation and subsequent invasions in the Southern Hemisphere in unravelling the determinants of invasive success. The understanding of the interacting roles of species traits, planting history, and environmental factors in determining whether or when invasions will occur, reinforced by modelling studies [26], has paved the way for the provision of guidelines on how to minimize the extent and impacts of invasions in new areas [21,27-30]. Options for switching to less invasive species for plantations are very limited, since less invasive or non-invasive pine species (or other species) are not productive enough to sustain commercial forestry. Given the obvious role of prolific seed production (high propagule pressure) in driving invasions, an obvious solution is to reduce seed production. Options for achieving this in commercial pine forestry through seed-attacking biological control agents have been explored. At present this strategy has limited application since the best biocontrol candidates are also implicated in disease transmission, making the risk to commercial forestry too onerous [31]. Further research is urgently needed. Work is underway to explore options for producing sterile trees, and this option seems to hold promise [28]. In the interim, the most effective management strategy seems to be to integrate the following (listed in decreasing order of the spatial scale of the intervention):

- spatially explicit risk assessment at a national scale as a basis for objective demarcation of areas suitable for plantations [30];

- at the landscape scale, attention to plantation design (e.g., orientation in relation to prevailing wind), species composition, and optimum land management around plantations to reduce the incidence of invasions [32];

- at the scale of individual management units, the incorporation of mechanical control measures to curb spread at the edge of plantations as part of standard silvicultural operations; and the application of appropriate landscape management (system dependent, including fire and grazing management) to prevent the establishment and spread of invading plants in surrounding land.

The global significance of the forestry industry and the well developed international markets have helped to introduce best-practice procedures and certification standards, for example through the Forest Stewardship Council and the International Standards Organization [33]. Such developments are potentially important for reducing the effectiveness of commercial forestry operations as a pathway for alien trees and shrub invasions. Such interventions are relatively recent and it is too early to assess whether these, in combination with other strategies, will substantially reduce problems. The formal integration of such approaches into national legislation, for example in South Africa, is however encouraging.

\section{Agroforestry}

Agroforestry involves the integration of trees and shrubs with crops and/or animals in the same area, either in a spatial mixture or in a temporal sequence, to derive the combined benefits of all components. This form of silviculture has a much longer history than plantation forestry, 
stretching back many centuries. The widespread availability of thousands of species of non-native trees for the last century or so has, however, revolutionized agroforestry and related 'non-conventional' forestry activities, with profound implications for this practice as a pathway for invasions. Hundreds of tree species are now widely planted, especially in the tropics. Trees typically used in agroforestry may be divided into the following groups:

- Fast-growing, nitrogen-fixing legume trees: (e.g., Acacia spp., Calliandra calothyrsus, Gleditsia triacanthos; Gliricidia sepium, Leucaena leucocephala, Parkinsonia aculeata, and Senna spp.).

- Trees for dry zones (e.g., Acacia nilotica, Azadirachta indica, and Prosopis spp.).

- Non-legume service trees (e.g., Cecropia spp.).

- Fast-growing timber trees (e.g., Eucalyptus spp., Casuarina spp.).

- High-value timber trees (e.g., Cedrela odorata, Cordia alliodora).

- Fruit trees (e.g., Citrus spp., Psidium guajava).
In all these cases, both the selection of trees and the conditions into which they are planted favour invasive spread [34]. Agroforestry often strives towards multifunctional landscapes in which many needs are met by numerous plant species and land uses. In some cases, invasiveness of planted species is seen as beneficial, for example when spreading plants provide additional resources such as fuel wood. Indeed the concept of invasiveness as a problem in agroforestry is controversial in some situations as proponents of agroforestry argue that overall benefits to communities greatly outweigh potential damages through invasiveness. Nonetheless, many of the species listed above are transformer species [35] that radically alter ecosystems and reduce the sustainability of many forms of land use.

Many agroforestry enterprises are funded by international donor agencies and initiated by regional cooperatives. However, local-scale management is usually done by small-scale growers. Since products are generally for local consumption, international market forces do not dictate best-practice management, and local, regional and

Figure 1

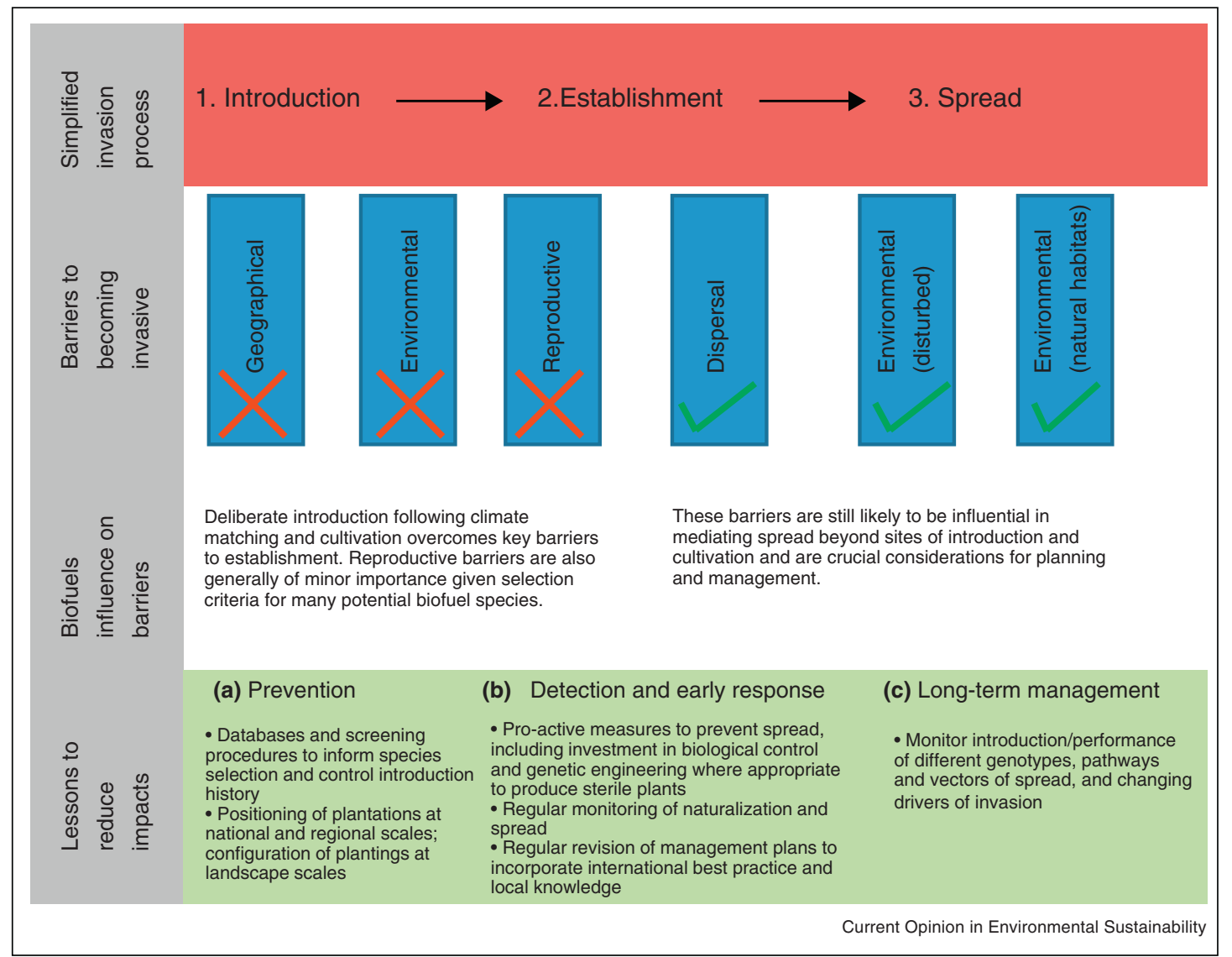

Schematic depiction of the main phases in the invasion process, potential barriers to invasion, ways in which likely scenarios for biofuel production using alien plants could influence the importance of barriers, and some lessons from the history of invasions in commercial forestry and agroforestry for limiting invasion problems in the plant biofuel industry. Barrier model adapted from Richardson et al. (2000). Three complementary strategies (prevent; detection and early response; and long-term management) from Chornesky et al. (2004). 
Table 1

Key lessons for dealing with invasions of alien plants used for biofuel production from the experience with invasions resulting from commercial forestry and agroforestry

\begin{tabular}{lll}
\hline Key lessons & Details & To ensure that biofuels production \\
\hline $\begin{array}{l}\text { Some species are } \\
\text { inherently better } \\
\text { invaders than } \\
\text { others }\end{array}$ & $\begin{array}{l}\text { Global lists of the most invasive taxa are now available. If } \\
\text { species are invasive in one region, they are very likely to } \\
\text { replicate this in similar environments elsewhere. This is } \\
\text { useful for compiling 'black lists' of known invasive species } \\
\text { which should either not be used, or which demand special } \\
\text { attention if used. }\end{array}$ & $\begin{array}{l}\text { High-risk species, for example, Arundo } \\
\text { donax, should ideally be avoided. When } \\
\text { the used, special measures must be } \\
\text { mandatory Biological control or other } \\
\text { mitigation measures, such as the } \\
\text { development of sterile plants, could } \\
\text { potentially be applied. }\end{array}$
\end{tabular}

Invasion success Problems with invasions increase as the size of the increases with increasing propagule pressure and time since introduction

Prolific seed production spells trouble

Genetic change due to the introduction and cultivation history can favour invasiveness -

Mutualisms are crucial, and reshuffling the world's biota is making ecosystems more open to invasion by more species propagule pool and the time since introduction increase. High propagules pressure can result in successful invasions, even if the environment is sub-optimal for establishment of the species.

Various aspects of seed biology are important determinants of invasiveness. Heavy seed production in the absence of natural enemies is a crucial factor in many plant invasions. Very large seed numbers can swamp regeneration microsites, resulting in invasion, even in marginal sites. Heavy seed production affects dispersal in several ways. More seeds usually result in more offspring further from parent plants. Biological control using seedattacking insects can reduce seed production of some desirable species without affecting other features of the species.

Changes in the genetic make-up of introduced species can change their ability to invade. This may be as a result of the evolution of land races, increased genetic diversity as a result of the introduction of new genotypes, spontaneous hybridization in situ, or to human-mediated breeding programs aimed at genetic improvement. Spontaneous interspecific hybridization is important for the evolution of invasiveness in plants. Hybridization potentially changes the 'game rules' for an alien organism, and may enhance its ability to become established and invasive because of increased vitality of the hybrids compared with the parent species.

Many invasions rely on mutualistic interactions between the introduced plant species and other organisms (e.g., animal-mediated pollination and seed dispersal, and interactions between plant roots and mycorrhizal fungi and nitrogen-fixing bacteria). Generalist vertebrate seed dispersers such as livestock are frequently a component of agroforestry systems, and provide a reliable mechanism for seed movement. Propagules of many agroforestry trees are widely disseminated by humans. These factors contribute to enhanced long-distance dispersal and the establishment of new foci for invasion. Potential barriers to establishment (and invasion beyond planting sites) are overcome for many agroforestry trees and shrubs when appropriate mycorrhizal symbionts and bacteria are introduced. Such inoculations enable the alien agroforestry species to grow productively in the new habitat, but also radically enhance the suitability of surrounding areas for establishment/invasion by the alien species.
Many biofuel plantations are likely to be established over large areas. Special precautions are needed to confine seeds and vegetative materials to the planted area and to minimize spread along transport routes. Location and configuration of the plantings in relation to the surrounding habitat are crucial for minimizing invasions (e.g., planting near riparian zones or degraded landscapes highly susceptible to invasion).

Some biofuel crops are dependent on high seed production with species being specially selected and bred to maximise this trait. In such instances seed-attacking insects may not be a viable option in this industry and use of the biocontrol could be limited.

Some species are chosen due to the range of genetic stock that can increase productivity, growth rates and pest resistance.

The risks of genes escaping, resulting in hybridization in adjacent populations is a serious and unquantifiable risk.

Prior introduction of many mutualists for forestry, agroforestry and other uses will enhance invasibility of many ecosystems for species to be used for biofuels. This means that lag phases between introduction and the onset of invasive spread will be shorter for biofuels than those reported for forestry and agroforestry. 
Table 1 (Continued)

\begin{tabular}{|c|c|c|c|}
\hline Key lessons & Details & To ensure that biofuels production & $\begin{array}{l}\text { Key } \\
\text { references }\end{array}$ \\
\hline $\begin{array}{l}\text { Potential impacts } \\
\text { of invaders are } \\
\text { often related to } \\
\text { the functions and } \\
\text { services that } \\
\text { make these } \\
\text { species } \\
\text { desirable } \\
\text { subjects for } \\
\text { cultivation }\end{array}$ & $\begin{array}{l}\text { Alien plant species for forestry and agroforestry are } \\
\text { selected for the new functions and services that they bring } \\
\text { to the system - functions and services that cannot be } \\
\text { provided (as well) by native species. Often, it is exactly } \\
\text { these functions/services (e.g., rapid biomass } \\
\text { accumulation, nitrogen fixation) that cause harmful } \\
\text { impacts when these species invade beyond sites } \\
\text { intended for agroforestry. }\end{array}$ & $\begin{array}{l}\text { To ensure that biofuel do not compete with } \\
\text { food resources for land, marginal and } \\
\text { degraded land is being targeted for biofuel } \\
\text { production. }\end{array}$ & \\
\hline $\begin{array}{l}\text { The history of } \\
\text { experimentation } \\
\text { with many } \\
\text { species } \\
\text { worldwide } \\
\text { ensures better } \\
\text { species-site } \\
\text { matching than in } \\
\text { the past - fewer } \\
\text { failures and more } \\
\text { invaders }\end{array}$ & $\begin{array}{l}\text { Improved R\&D in many parts of the world has resulted in } \\
\text { the rapid and widespread dissemination of news of highly } \\
\text { successful agroforestry species (e.g., the many species of } \\
\text { 'wonder trees'). Such information, based on the natural } \\
\text { experiment of the planting of hundreds of species across } \\
\text { the world is, in effect, providing empirical evidence on } \\
\text { species-site matching. Rather than needing to } \\
\text { experiment with a large number of potential species, } \\
\text { agroforesters are now able to select from a small number } \\
\text { of species with a very high chance of success in their area. } \\
\text { Species selection following this process is, in many } \\
\text { cases, also selecting for invasiveness. }\end{array}$ & $\begin{array}{l}\text { Biofuel crops may benefit from advanced } \\
\text { site-selection and climate-matching } \\
\text { criteria for maximising productivity. The } \\
\text { positive implication is that chances of } \\
\text { failure of feedstock species will be } \\
\text { reduced, resulting in a lower risk of } \\
\text { abandonment of plantings. }\end{array}$ & {$[6,48,49]$} \\
\hline $\begin{array}{l}\text { Unravelling the } \\
\text { drivers of } \\
\text { planting is crucial }\end{array}$ & $\begin{array}{l}\text { The dimensions of planting of alien tree species are } \\
\text { shaped by ecological, economic, cultural, and political } \\
\text { factors that differ considerably in different parts of the } \\
\text { world. These factors are totally different for different types } \\
\text { of enterprises in commercial forestry and agroforestry. } \\
\text { These drivers, together with a range of ecological factors } \\
\text { that determine levels of invasiveness and invasibility, } \\
\text { define the extent and magnitude of the problem and } \\
\text { delineate options for intervention. }\end{array}$ & $\begin{array}{l}\text { Biofuels are expected to play a diverse role } \\
\text { in future bioeconomies - driving factors } \\
\text { will include ecological, economic, cultural, } \\
\text { and political factors. The crucial roles of } \\
\text { energy security, poverty alleviation and } \\
\text { climate-change need to be integrated with } \\
\text { environmental concerns, including } \\
\text { provision related to invasiveness. }\end{array}$ & {$[1]$} \\
\hline
\end{tabular}

national authorities have little power to implement binding regulations to manage for invasions originating from such ventures. The large number of tree species used for agroforestry and the diversity of planting configurations and contexts (from highly degraded systems to intact systems adjoining sensitive conservation areas), usually makes it impractical to enact effective regional strategies to mitigate problems. Biological control is a crucial form of control in such situations and notable successes have been achieved but the problem is escalating in severity in many areas. Successes have been reported in some areas through substituting invasive alien species with less invasive alien, or native, species. However, as with commercial forestry, a fairly small number of alien plants (including a number of 'wonder plants' that fulfil multiple objectives) are difficult or impossible to replace.

\section{Ultimate causes of problems of invasiveness in forestry and agroforestry}

There are two key components among the fundamental drivers of plant invasions resulting from intentionally introduced and widely cultivated trees and shrubs. The first relates to the traits of the species. For both forms of forestry, rapid growth rates, and various properties associated with hardiness, and adaptability to a range of, often harsh, conditions have been strongly selected for. These, and other properties, such as precocious and prolific seed production, desirable in many agroforestry situations, make these species inherently weedy. Richardson [36] wrote of 'invasive alien trees: the price of forestry'. The second crucial driver of problems in this regard relates to dimensions of the pathways forged by all aspects of the cultivation of non-native trees. Aspects that strongly influence invasions include these:

- The alien species are often planted in massive numbers over large areas, ensuring huge sources of propagules.

- The configuration of plantings creates good conditions for initiating invasions. In the case of large plantations, there is often a long edge adjoining invasible habitat. In most agroforestry ventures, rows of trees or scattered trees form effective foci for seed dispersal.

- Plantings often adjoin natural or areas of semi-natural vegetation that are often managed for other uses, creating acute conflicts of interest when invasions occur.

- Establishment of the trees is often accompanied by disturbance (to reduce competition from native 
vegetation) and the intentional introduction of mutualists such as mycorrhizal fungi for pines and rhizobia for legume trees. This favours growth and recruitment of the alien trees, not only in areas identified for silviculture but also in surrounding areas.

\section{Current biofuel trends}

The impetus for biofuel production to expand rapidly to contribute to national energy security, rural-development and other priorities means that production is likely to grow rapidly, posing special problems for planning to ensure sustainability and to minimize environmental damage. To meet targets a combination of large-scale commercial production and small scale farming opportunities may need to be realised $\left[37^{\circ}\right]$. On the one hand, biofuels are expected to play a relatively large role in mitigating carbon emissions in a short time which could result in the development of large scale plantations mainly in developing countries [38,39]. Owing to various technological and feedstock limitations none of these scenarios have yet moved beyond experimentation. Certification bodies and international conservation organisations have taken the opportunity to caution against the lack of standardization and certification process. At the other end of the spectrum, the biofuel boom has stimulated interest in developing small-scale bioenergy production to uplift rural communities and improve livelihoods without compromising food security or environmental integrity $\left[38,40^{\bullet \bullet}\right]$. However, history shows that 'wonder crops' soon lose their appeal and become pests for the very reasons they were initially chosen. Robust strategies are needed now, to avoid the problems with invasive species that bedevil commercial forestry and agroforestry (Figure 1).

Screening protocols and global databases of invasive species are powerful tools for arriving at informed decisions regarding the introduction of new species. The lessons from forestry and agroforestry are particularly useful in selecting species and developing appropriate management options (Table 1). We can adopt existing management and legislative models to minimize the impacts of using alien plants in new environments. The challenge will be to develop standards that can be applied to both small and large-scale operations and in a range of socio-political milieus.

\section{Conclusions}

Commercial forestry and agroforestry are the closest analogs to biofuel production because of the types of plants that are used and the scale and configurations of plantings. Hard lessons have been learnt in these fields, some of which can be applied to avoid some of the pitfalls that have been experienced. There are, however, also other fields in the emerging bioeconomy that rely on nonnative species and where problems with invasiveness of subject taxa cause problems - horticulture [41] and aquaculture [42]. The socio-economic drivers of each of these enterprises are very different and much work remains to be done to craft innovative ways of making such industries, with inherently high risks of exacerbating escalating problems with biological invasions, sustainable.

\section{References and recommended reading}

Papers of particular interest, published within the period of review, have been highlighted as:

- of special interest

$\bullet$ of outstanding interest

1. Tilman D, Socolow R, Foley JA, Hill J, Larson E, Lynd L, Pacala S, Reilly J, Searchinger T, Somerville $\mathrm{C}$ et al.: Beneficial biofuels the food, energy, and environment trilemma. Science 2009, 325:270-271.

2. Davis AS, Cousens R, Hill J, Mack RN, Simberloff D, Raghu S: Screening bioenergy feedstock crops to mitigate invasion risk. Front Ecol Environ 2010, 8:533-539.

3. Koh LP, Levang P, Ghazoul J: Designer landscapes for sustainable biofuels. Trends Ecol Evol 2009, 24:431.

4. Pimentel D, Marklein A, Toth MA, Karpoff MN, Paul GS, McCormack R, Kyriazis J, Krueger T: Food versus biofuels: environmental and economic costs. Human Ecol 2009, 37:1-12.

5. Leakey ADB: Rising atmospheric carbon dioxide concentration and the future of $\mathbf{C 4}$ crops for food and fuel. Proc Roy Soc B: Biol Sci 2009, 276:2333-2343.

6. Barney JN, DiTomaso JM: Bioclimatic predictions of habitat suitability for the biofuel switchgrass in North America under current and future climate scenarios. Biomass Bioenergy 2010, 34:124-133.

7. Buddenhagen CE, Chimera C, Clifford $P$ : Assessing biofuel crop -. invasiveness: a case study. PLOS ONE 2009, 4:e5261.

8. Barney JN, DiTomaso JM: Nonnative species and bioenergy: are we cultivating the next invader. BioScience 2008:64-70.

9. Raghu S, Anderson RC, Daehler CC, Davis AS, Wiedenmann RN, Simberloff $D$, Mack RN: Adding biofuels to the invasive species fire? Science 2006, 313:1742-11742.

10. Simberloff $D$ : Invasion biologists and the biofuels boom: Cassandras or colleagues? Weed Sci 2008, 56:867-872.

11. Groom MJ, Gray EM, Townsend PA: Biofuels and biodiversity: principles for creating better policies for biofuel production. Conserv Biol 2008, 22:602-609.

12. IUCN: Guidelines on biofuels and invasive species. Gland, Switzerland: IUCN; 2009:. 20pp.

13. Miller C, Kettunen M, Shine C: Scope Options for EU Action on Invasive Alien Species (IAS): Final Report for the European Commission Brussels, Belgium: Institute for European Environmental Policy (IEEP); 2006:. p. 109.

14. Low T, Booth C: The Weedy Truth about Biofuels. Melbourne, Australia: Invasive Species Council; 2007:. 46 p.

15. Crosti $R$, Cascone $C$, Cipollaro $S$ : Use of a weed risk assessment for the Mediterranean region of Central Italy to prevent loss of functionality and biodiversity in agro-ecosystems. Biological Invasions 2010, 12:1607-1616.

16. Connor DJ, Hernandez CG: Crops for biofuels: current status and prospects for the future. In In Biofuels: Environmental Consequences and Interactions with Changing Land Use. Proceedings of the Scientific Committee on Problems of the Environment (SCOPE) International Biofuels Project Rapid Assessment; Gummersbach, Germany. Edited by Howarth RW, 
Bringezu S. Biofuels: Environmental Consequences and Interactions with Changing Land Use. Proceedings of the Scientific Committee on Problems of the Environment (SCOPE) International Biofuels Project Rapid Assessment; Gummersbach, Germany Ithaca NY, USA: Cornell University; 2009:65-80.

17. Richardson DM: Forestry trees as invasive aliens. Conserv Biol 1998, 12:18-26.

18. Richardson DM: Forestry and agroforestry. In Encyclopedia of Biological Invasions. Edited by Simberloff D, Rejmánek M: University of California Press; 2011:241-248.

19. Brockerhoff EG, Jactel H, Parrotta JA, Quine CP, Sayer J: Plantation forests and biodiversity: oxymoron or opportunity? Biodivers Conserv 2008, 17:925-951.

20. Richardson DM, Higgins SI: Pines as invaders in the southern hemisphere. In Ecology and Biogeography of Pinus. Edited by Richardson DM. Cambridge University Press; 1998:450473.

21. Simberloff D, Nuñez M, Ledgard NJ, Pauchard A, Richardson DM, Sarasola M, van Wilgen BW, Zalba SM, Zenni RD, Bustamante R et al.: Spread and impact of introduced conifers in South America: lessons from other southern hemisphere regions. Austral Ecol 2010, 35:489-504.

22. Richardson DM, Williams PA, Hobbs RJ: Pine invasions in the Southern Hemisphere: determinants of spread and invadability. J Biogeogr 1994, 21:511-527.

23. Rejmánek M, Richardson DM: What attributes make some plant species more invasive? Ecology 1996, 77:1655-1661.

24. Richardson DM, Rejmánek M: Invasive conifers: a global survey and predictive framework. Divers Distrib 2004, 10:321-331.

25. Rejmánek M, Richardson DM, Higgins SI, Pitcairn MJ, Grotkopp E: Ecology of invasive plants - state of the art. In Invasive Alien Species: A New Synthesis. Edited by Mooney HA, Mack RN, Mc Neely JA, Neville L, Schei PJ, Waage J. Island Press; 2005:104161.

26. Higgins SI, Richardson DM: Pine invasions in the southern hemisphere: modelling interactions between organism, environment and disturbance. Plant Ecol 1998, 135:79-93.

27. Langdon $B$, Pauchard $A$, Aguayo M: Pinus contorta invasion in the Chilean Patagonia: local patterns in a global context. Biol Invas 2010, 12:3961-3971.

28. Richardson DM, Petit R: Pines as invasive aliens: outlook on transgenic pine plantations in the Southern Hemisphere. In Landscapes, Genomics and Transgenic Conifers. Edited by Williams CG. Springer; 2005:169-188.

29. Richardson DM, van Wilgen BW, Nuñez M: Alien conifer invasions in South America: short fuse burning? Biological Invasions 2008, 10:573-577.

30. Rouget M, Richardson DM, Nel JA, van Wilgen BW: Commercially important trees as invasive aliens - towards spatially explicit risk assessment at a national scale. Biol Invas 2002, 4:397-412.

31. Moran VC, Hoffmann JH, Donnnelly D, Van Wilgen BW, Zimmermann HG: In Biological Control of Alien, Invasive Pine Trees (Pinus species). South Africa Proceedings of the $X$ International Symposium on Biological Control of Weeds. Edited by Spencer NR. Biological Control of Alien, Invasive Pine Trees (Pinus species). South Africa Proceedings of the $X$ International Symposium on Biological Control of Weeds Bozeman, Montana, USA: Montana State University; 2000:941-953.

32. Ledgard NJ, Langer ER: Wilding Prevention. Guidelines for Minimising the Risk of Unwanted Wilding Spread from New Plantings of Introduced Conifers. New Zealand Forest Research Institute Limited; 1999.
33. Richardson DM, Cambray JA, Chapman RA, Dean WRJ, Griffiths CL, Newton DJ, Winstanley TJ: Vectors and pathways of biological invasions in South Africa: past, present and future. In Invasive Species Vectors and Management Strategies. Edited by Ruiz G, Carlton JT. Island Press; 2003:292-349.

34. Richardson DM, Binggeli P, Schroth G: Invasive agroforestry trees: problems and solutions. In Agroforestry and Biodiversity Conservation in Tropical Landscapes. Edited by Schroth G, Harvey CA, Gascon C, Vasconcelos H, Izac A-MM.. Island Press; 2004:371-396.

35. Pyšek $P$, Richardson DM, Rejmánek $M$, Webster GL, Williamson M, Kirschner J: Alien plants in checklists and floras: towards better communication between taxonomists and ecologists. Taxon 2004, 53:131-143.

36. Richardson DM: Invasive alien trees: the price of forestry. Invaders from Planet Earth World Conservation Double Issue. IUCN; 1998: 14-15, vols. 4/97-1/98.

37. Fischer G, Hizsnyik E, Prieler S, Shah M, van Velthuizen H: Biofuels

- $\quad$ and Food Security. Laxenburg: Study commissioned by the OPEC Fund for International Development, International Institute for Applied Systems Analysis; 2009.

A useful summary on current and future implications for food production including implications of technological innovation in biofuel processing techniques.

38. Vermeulen S, Sulle E, Fauveaud S: Biofuels in Africa: growing small-scale opportunities. IIED Business Models for Sustainable Development. IIED; 2009.

39. Koh LP: Impacts of land use change on South-east Asian forest butterflies: a review. J Appl Ecol 2007, 44:703-713.

40. Achten WMJ, Maes WH, Aerts R, Verchot L, Trabucco A, Mathijs E,

- Singh VP, Muys B: Jatropha: from global hype to local opportunity. J Arid Environ 2010, 74:164-165.

Presents an alternative view of benefitting rural populations in the absence of economically viable large-scale plantations.

41. Reichard $\mathrm{SH}$, White $\mathrm{P}$ : Horticulture as a pathway of invasive plant introductions in the United States. BioScience 2001, 51:103-113.

42. Naylor RL, Williams SL, Strong DR: Aquaculture - a gateway for exotic species. Science 2001, 297:1655-1656.

43. Křivánek $M$, Pyšek $P$, Jarošík V: Planting history and propagule pressure as predictors of invasion by woody species in a temperate region. Conserv Biol 2006, 20:1487-1498.

44. Wilson JRU, Dormontt EE, Prentis PJ, Lowe AJ, Richardson DM:

- Something in the way you move: dispersal pathways affect invasion success. Trends Ecol Evol 2009, 24:136-144.

45. Firbank L: Assessing the ecological impacts of bioenergy -. projects. Bioenergy Res 2008, 1:12-19.

Compares lessons from genetic modified organisms with potential impacts from biofuel at various scales.

46. McGeoch MA, Kalwij JM, Rhodes JI: A spatial assessment of Brassica napus gene flow potential to wild and weedy relatives in the fynbos biome. South Af J Sci 2009, 105:109-115.

47. Kumar RS, Parthiban KT, Hemalatha P, Kalaiselvi T, Rao MG: Investigation on cross-compatibility barriers in the biofuel crop Jatropha curcas L. with wild Jatropha species. Crop Sci 2009, 49:1667-1674.

48. Traveset A, Richardson DM: Mutualisms - key drivers of invasions... key casualties of invasions. In Fifty Years of Invasion Ecology. Edited by Richardson DM. Wiley-Blackwell; 2010:143-160.

49. Maes WH, Trabucco A, Achten WMJ, Muys B: Climatic growing conditions of Jatropha curcas L. Biomass Bioenergy 2009, 33:1481-1485. 